\title{
INTERPRETING NON-CHRISTIAN CULTURES: JESUIT BIASES
}

Historians today agree that the Jesuit interpretation of foreign nations was biased and needs to be treated carefully. In Canadian historiography, for example, there remain three questions on the Jesuit observations of native peoples and their culture. First, in what way and at what points are the Jesuit observations about the First Nations wrong and distorted? Second, given that the European missionaries were prejudiced in their interpretations, what were their biases and mistakes? Third, what are the alternative explanations of the non-Christian cultures, based on the answers to these two earlier questions?

Answering these questions is not an easy task, for the lack of written indigenous documents has forced scholars to revise missionary interpretations by relying on speculation, albeit cautious speculation. It is also well known to scholars who have studied human psychology that understanding by analogy will always be the first approach to a newlyencountered, foreign culture. Given the absence of counter-evidence from the voiceless indigenous peoples, one may find it difficult to identify the European or Christian biases and errors in one-sided observations. It may be impossible to tell how inaccurate the Jesuit interpretation of native Canadian cultures is so long as the consideration remains within a limited North American scope. By contrast, Japan's language, culture and tradition have survived, which thus allows more scope for modern researchers to identify the misinterpretations made by western missionaries about the Japanese.

A tangible identification of European missionary biases, at least better than one based merely on ambiguous speculations, is possible through examination of the mission in Japan. Japanese historical knowledge may help to verify the misinterpretations of the Jesuits. The Jesuit experience in this archipelago will help to answer the first and second questions above. The general identification of western biases can then be transferred to the North American context in order to find clues that may answer the third question.

The sections below will make a threefold argument. First, Jesuit interpretations of Japanese culture will be contrasted with Japanese 
reality that can be recognised from a thorough non-European standpoint and thus is independent of the influence of Euro-Christian missionaries. This contrast will reveal the probable epistemological mistakes and cultural biases of the priests. Second, this identification of misunderstandings and biases will be applied to the written cultural observations of the evangelistic successors, the Jesuits of New France. Third, probable biases will be eliminated from the reading of the French missionary accounts to arrive at a more plausible image of several aspects of Amerindian culture.

\section{A. The Jesuit Interpretation of Japanese Culture}

To prepare for effective preaching, the Jesuits in Japan attempted a thorough observation of the nation, as is documented in their correspondence. The Jesuit biases are evident in two categories of observations. One group consists of first-hand observations based mainly on their five senses, while the other group consists of second-hand observations or knowledge acquired from local informants.

\section{First-hand Observations}

Direct observations can be found in the descriptions of the Japanese people. In the first place, this type of description was influenced by what may be called a wilful manipulation of direct observations. An example can be found in two letters of Father Francisco de Xavier. One letter admires the Japanese people while the other criticises them. In his letter of 5 November 1549, only three months after his arrival at Kagoshima, Father Xavier commented:

First of all, the people with whom we have thus far conversed are the best that have as yet been discovered; and it seems to me that no other pagan race will be found that will surpass the Japanese. They have, as a race, very fine manners; and they are on the whole good and not malicious. They have a marvellous sense of honour and esteem it more than anything else. As a race they are generally poor, but the poverty that is found among the nobles and those who are not is not deemed to be a matter of reproach. ${ }^{1}$

1 To his companions living in Goa, from Kagoshima, 5 November 1549, in M. Joseph Costelloe, SJ (ed.), The Letters and Instructions of Francis Xavier (St. Louis, Missouri: The Institute of Jesuit Sources, 1992), epistola [ep., hereafter] 90, p. 297, in 
In another letter addressed to Father Simão Rodrigues in Portugal, dating 8 April 1552, after he left Japan for India, he related:

...they [Carlos V, Spanish Emperor, and Felipe and Isabella, the king and queen of Castile] should not send any more fleets from New Spain to discover Silver Islands [Japan]; for... they would be lost; and even if they were not lost at sea and reached the islands of Japan, the people there are so belligerent and avaricious that they would seize all the ships coming from New Spain.... Further, as I have already indicated, the Japanese are so greedy that they would slay all of them in order to obtain their weapons and the wares.... ${ }^{2}$

These remarks by Father Xavier are not contradictory, even though they appear so. He did not intend to deceive his correspondents. He simply emphasised two different aspects of the nation, with two different purposes in mind. He was a pioneer missionary to Japan. When he sent the letter in 1549 , he had to justify his choice of this nation as the object for Christianisation, and pointed to the positive aspects of the people. In Japan, he had limited access to overseas information, but once in Goa, he obtained more information about Spanish colonisation in the South China Sea. The Portuguese and Spanish in East Asia were about to enter into conflict in the 1550s. According to his second letter, he learnt of a Spanish plan to reach Japan from the Philippines, which had just been conquered by the Spanish fleet. Either he wanted to maintain the Jesuit monopoly of the mission over Japan by dissuading Spanish Friars; or he was worried about a war between Spain and Portugal over Japan, whose silver mines were invaluable. Thus, he urged Father Rodrigues to speak on his behalf to the Spanish emperor directly, or indirectly through the Portuguese King or Queen. Depending on Father Xavier's objectives, the Japanese were either well suited to become Christians or a belligerent enemy of Iberian colonisation. This comparison of two apparently contradictory passages by Father Xavier shows that missionary descriptions were determined pragmatically by current intentions.

In the second place, the Jesuit observations of the Japanese were influenced by interpretive biases. Because of their European and Christian origin, Jesuit missionaries were prone to interpret their experience by

Kôno Yoshinori, SJ (ed.), Sei Furanshisuko Zabieru zenshokan (Tokyo: Heibon-sha, 1985), ep. 90, p. 471.

2 To Father Simão Rodrigues, in Portugal, from Goa, 8 April 1552, in Costelloe, op. cit., ep. 108, p. 378, Kôno, op. cit., ep. 108, pp. 617-18. 
what they believed to be common sense. The Jesuit observations cover a wide spectrum of Japanese culture, which include two basic groups of subjects. The first group comprises climate, weather, diet, agricultural product, protocol, peace and order, and architecture. Except in rare cases, the missionaries normally made objective interpretations on these topics. The second group involves physical appearance and behavioural patterns. It is mainly in the observations of these second themes that the Jesuits were unable to escape their interpretive biases.

To the Jesuits, physical appearance was the first detectable difference. Their criterion for judging was apparently skin colour-the lighter the better. In 1565, Father Luis Frois wrote that the people of Japan had fair skin and a well-proportioned physique. ${ }^{3}$ The same year, Father Gaspar Vilela shared the same observation by noting that the complexion of every Japanese was fairer than that of the Portuguese. ${ }^{4}$ The Jesuit fathers used the references to fair complexions for their appraisal of the people whom they intended to Christianise.

A contrast is found in the observations of the Visiting Father, or padre visitador, Alessandro Valignano's confidential letter to the Jesuit general superior. Father Valignano criticised Father Francisco Cabral, ex-vice-superior of Japan, and wrote that Father Cabral erred in dealing with Japanese brothers by treating them like servants. According to Josef Franz Schütte, SJ, who thoroughly studied Father Valignano's confidential correspondence preserved in Rome, the visiting father wrote in 1595 that Father Cabral had spoken to them harshly and angrily and had called them 'Negroes [Neger]' and 'low-class people [niedriges Volk]'..$^{5}$ In this case, Father Cabral used the colour of skin in order to demean his Japanese colleagues. The colour of a non-European

${ }^{3}$ Luis Frois, to his companions in India and China, from Kyôto, 20 February 1565, in Matsuda Kiichi et al. (eds.), 3rd ser. of Jûroku-shichi seiki Iezusukai Nippon hôkokushû (Kyôto: Dôhô-sha, 1988-1996), vol. 2, 304-05 [hereafter, Matsuda, Hôkokushû 3, 2: 304-05].

${ }^{4}$ Gaspar Vilela, to the fathers in Avis, Portugal, from Sakai, 15 September 1565, in Matsuda, Hôkokush û 3, 3: 20-21. Cf. Okada Akio (ed.), Yôroppa bunka to Nippon bunka (Tokyo: Iwanami shoten, 1991), 18.

${ }^{5}$ These phrases are based on Josef Franz Schütte's citation of a letter of Alessandro Valignano, to the general superior in Rome, from Goa, 23 November 1595. Schütte writes, 'er [Cabral] sprach sehr hart zu ihnen und mit viel Zorn, nannte sie Neger, niedriges Volk, und gab ihnen andere beleidigende und unhöfliche Ausdrücke.' Father Valignano's original Latin words are not quoted. See Josef Franz Schütte, SJ, Valignanos Missiongrundsätze für Japan (2 parts, Roma: Edizioni de Storia E Letteratura, 1951-58), part 1, 325-31, esp. 325; and Josef Franz Schütte, SJ, Valignano's Mission Principles for Japan (2 parts, St. Louis: The Institute of Jesuit Sources, 1980), part 1, 255-60, esp. 255. 
complexion was described either 'as fair as Europeans' or 'as dark as Africans', depending on intent.

More detailed descriptions are found in Father Frois's cultural comparison between Europe and Japan, whose long title ends with Europa e esta provincia de Japão [Cultural Comparison, henceforth]. ${ }^{6}$ The content of his comparison, often irrelevant to evangelistic promotion, may have been useful only to his brethren in Japan and may have been insufficient for enlightening European readers. The manuscript thus remained unpublished throughout the missionary period. Although this pamphlet represents overall an objective comparison, it contains some remarks that suggest his cultural prejudice. For instance, Father Frois seems to have found it difficult to understand the metaphorical proof of bravery in war as demonstrated by a scar on the face. He noted that 'while we Europeans consider ourselves to be ugly with a scar on the face, Japanese men are proud of their ugly scarred face that they do not treat well'. Second, he did not agree with the fashion among the wealthy men, who wore patchwork coats decorated with brocades of gold and other attractive colours. He remarked that while patchworks were extremely demeaning to Europeans, the Japanese nobility treasured a whole patchworked qimão [kimono] or dóbuqu [dôbuku, a kind of overcoat for the upper classes]. Third, he commented, with reference to a fur dôbuku, that 'it would be insane for us to wear uncut and unsewn clothes'. Fourth, as far as he was concerned, walking without socks was unacceptable even in the humid climate of Japan. He wrote that if a woman strolled around without socks, Europeans ['we', including Frois] would think her crazy or shameless. Fifth, he was also unable to appreciate the smell of natural hairdressing oils for women. He noted that, while European women rendered their hair fragrant with perfumes, Japanese women always smelt foul because of the oil on their hair.?

Father Frois also condemned Buddhism. The Jesuits were displeased with anything that they believed was unacceptable to Christianity. They considered pagan idols hideous and inferior to Christian images. Father Frois related that while Christian icons were beautiful and induce devotion, Japanese Buddhist icons were unsightly and instilled

${ }^{6}$ Tratado em que se contem muito susintae abreviadamente algumas contradições e diferenças de custumes antre a gente de Europa e esta provincia de Japão (1585). The text this study uses is Okada Akio (ed.), Yôroppa bunka to Nippon bunka (1965, Tokyo: Iwanami shoten, 1991).

${ }^{7}$ Okada, op. cit., chap. 1, articles [art., hereafter] 11, $41 \&$ 57; chap. 2, art. 4 \& 20. 
feelings of horror because they resembled Satan being consumed by fire. ${ }^{8}$ According to Father Vilela, in another document, there were ugly drawings in those shrines that were dedicated to the sun, the moon, or a demon itself. ${ }^{9}$

\section{Second-hand Observations}

The Jesuit biases were not limited to first hand observations. They also acquired information indirectly. This indirect information gleaned from their native informants was filtered through a Jesuit bias. The missionaries' foci in their accounts were what they considered to be pagan religions and social structures. These were the two aspects of Japanese culture that they needed to study for combating paganism and for gaining local support in a foreign country.

\section{a. Interpreting Non-Christian Worship}

To begin with, the Jesuits relied on a Christian framework in order to interpret Buddhism, Shintô, and other forms of worship. In 1552, for example, to identify the Japanese deity, or to constitute a parallel to the Christian God, Father Xavier looked for a Supreme Being that was the object of Japanese worship, since he assumed that there must be a single God-like Being that was worshipped in Japan. He identified Shaka and Amida as the two main Buddhist idols for worship and pointed to the sun and the moon as other objects of veneration. Another appellation he applied to each of them was 'demon', which he and his brethren should defeat with God's help. ${ }^{10}$ Along the same lines, in 1557, Father Vilela also tried to discover what object or 'god' the Japanese would worship. He enumerated Amida, Shaka, the sun, the moon and demon-representing beasts. ${ }^{11}$ Father Cosme de Torres added kannon, a bodhisattva, to this list in $1561 .^{12}$ It was in 1585 when Father Frois categorised these objects of worship into two groups of

${ }^{8}$ Okada, op. cit., chap. 5, art. 8.

9 Gaspar Vilela, to his companions in India and Portugal, from [Hirado,] Japan, 29 Octber 1557, in Matsuda, Hôkokushû 3, 1: 263.

${ }^{10}$ Francisco de Xavier, to his companions in Europe, from Cochin, 29 January 1552; Xavier, to his companions in Goa, from Kagoshima, 5 November 1549, in Costelloe, ep. 90 \& 96, 298, 327 \& 336-37, in Kôno, ep. 90 \& 96, 472-73, 522 \& 536.

${ }_{11}$ Gaspar Vilela, to his companions in India and Portugal, from [Hirado,] Japan, 29 Octber 1557, in Matsuda, Hôkokush û 3, 1: 262-63.

${ }_{12}$ Cosme de Torres, to Antonio de Quadros in India, from Bungo, 8 October 1561, in Matsuda, Hôkokushû 3, 1: 340-41. 
deities: 'kami', or Japanese deities, and 'hotoke', or Buddhas. In Father Frois's statement, Buddhas included Shaka, Amida and other Buddhist idols while the kami included, inter alia, the sun deity, the harvest deity and war deity. He noted that people sought the forgiveness and assistance that they would need in the afterlife from Buddha, and that they wished to obtain from the kami such material benefits as health, longevity, wealth, childbirths and victory in war. ${ }^{13}$

There is one misunderstanding in this search for worshipped objects. The Jesuits seem to have asserted that Buddhist icons represented the core of Buddhism just as God was at the core of Christianity. The problem was that they relied on a Christian paradigm, and thus they failed to understand that there was a mystical law at the core of Buddhism and that Shaka or Amida was the individual who was believed to have fulfilled this law and enlightened himself as a Buddha.

Even though they noted the absence of Christian thought among the Japanese, the Jesuits continued to interpret Japanese spirituality through the lens of Christianity. Probably assuming that the Apostle Thomas had preached Christianity in eastern parts of the Asian continent, a widely held myth since the first century, Father Frois affirmed that common Christian concepts, like the Creator, the Saviour, the immortality of the soul, the glory of God and eternal happiness, had disappeared, since Thomas's visit, from the memory or knowledge of the Japanese. ${ }^{14}$ Ironically this missionary interpretation depended heavily on these Christian frameworks, which, Father Frois admitted, were entirely absent among this nation.

Heaven was a key, and the Jesuits believed that it was a part of Japanese spirituality. Accordingly, at Sakai in the early 1560s, Father Vilela attempted to learn how people understood heaven. His account described what he considered to be a false heaven. His understanding was that the Japanese people believed in numerous heavens where saints welcomed their adherents. According to him, Kannon followers wished to reach a heaven located under the sea, and Amida sectarians would go to another heaven. ${ }^{15}$ His idea of this Buddhist heaven is problematic because a Christian concept of heaven does not

${ }^{13}$ Luis Frois, to the general superior, from Nagasaki, 27 August 1585, in Matuda, Hôkokushû 3, 7: 61-63.

${ }^{14}$ Luis Frois, to his companions in China and India, from Kyoto, 20 February 1565, in Matsuda, Hôkokushû 3, 2: 306-07.

${ }_{15}$ Gaspar Vilela, to his companions, from Sakai, 1562, in Matsuda, Hôkokush û 3, 2: $82-83$. 
lead to an understanding of the Buddhist afterworld. In Buddhism, people could go to a sky world above the human realm after death, but that is only the fifth world from the top in the Buddhist ten-level hierarchy of enlightenment and obviously not a desired physical destination. What Buddhists hope to reach in their afterlife is the world of Buddha, which they believe to exist at the summit, far above the sky. What Father Vilela considered to be the Japanese version of heaven can be either a one-level-higher sky or the highest spiritual state of Buddhism, or even some ambiguous confusion of both.

The Creation was another concept used by the Jesuits in their attempt to understand the Japanese idea of the world's origins. In 1563, Father Vilela heard about a Japanese concept of Creation from the people in Kyoto. He explained three ideas about this concept without clarifying their spiritual origins. The first one was a secular story. The world was initially shaped like an egg. When a storm broke it, the albumen became the sky and the yolk and shell became the sea and land, from which creatures were born. The second one was almost a Buddhist view although Father Vilela did not recognise it as such. The beginning of the world was nothingness with no creation or genesis myth, as in Christianity. Everything visible came into existence only through a natural power. Father Vilela did not recognise the Japanese idea of Creation directly within the range of what the Jesuits regarded as Japanese spirituality, and thus resorted to an ancient myth of this country. The archipelago of Japan was created in a huge lake by a kami called Izanami, and all the inhabitants were descendants of Izanami and his wife Izanagi. ${ }^{16}$

Also, the Christian concept of Sin, Judgement and Atonement informed the missionary understanding of Buddha's rôle in the afterlife. In 1571, Father Frois commented on what he took to be a Buddhist form of remission of sins. He failed to understand that there was no Japanese custom of begging Buddha for the forgiveness of sin at the time of death. In the text, Father Frois made his Japanese Buddhist informant say that whichever sin one commits, merciful Shaka would forgive every sin with the help of his virtuous deeds. Father

\footnotetext{
16 Gaspar Vilela, to his companions in India, from Sakai, 27 April 1563, in Mat-

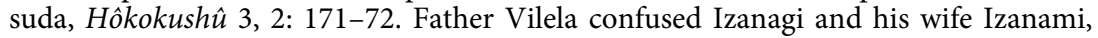
and quoted them in the opposite way. Although Vilela seemingly did not notice the importance of the last story, it is indirectly relevant with Shintô. In the myth, Izanagi was the ancestor of the Japanese sun deity.
} 
Frois seemingly borrowed a Christian framework and simply replaced 'God' with 'Shaka', and 'heavenly love' with 'virtuous deeds'. ${ }^{17}$

One of the most frequent and extensively-used expressions of the Jesuit reporters was a demon or a devil. The notion of the devil is close to the Buddhist idea of ma, or māra in Sanskrit, which means the evil deity hindering virtuous deeds. In a pre-scientific society such as sixteenth-century Japan, the causes of bodily illness were thought of as evil spirits, which Shintô priests or other shamans would try to exorcise. In a similar way, the Jesuits ascribed serious sickness to demons throughout the second half of the sixteenth century. For example, when Brother Duarte da Silva was repeatedly faced with paroxysmstricken people in Kutami, in Bungo of Kyushu in 1555, he concluded that demons possessed them. Brother Miguel Vaz reported also on Kutami that a demon had possessed a diseased Christian woman who was inflicted with severe symptoms and almost died before she was helped by a Jesuit prayer. In the annual reports for 1583 and 1591-92, Father Frois referred to several ill residents in Bungo, who he believed were possessed by demons and had to be helped by the Christian faith. In this second report, Father Frois noted that demons ailed the bodies of people causing not only illness but also death. ${ }^{18}$ The Jesuits presented no other possibility in diagnosing paroxysms and diseases.

The Jesuits, however, extended the term of devils or demons to a wider spectrum of life and used the term casually. A dualistic attitude to God and His enemy seems to have persuaded them to deem any spirit that they found against God to be demons. To be more precise, 'the meditation of the two standards' in The Spiritual Exercises written by Father Ignatius de Loyola is likely to have encouraged this concept of duality. According to Father Loyola, Christian life is a struggle between the poles of Jesus Christ and of Lucifer. This first general superior was a former soldier who organised the Society of Jesus along

${ }^{17}$ Luis Frois, from Kyoto, 10 March 1571, the recipient is missing, in Matsuda, Hôkokushû 3, 4: 57-58.

${ }_{18}$ Duarte da Silva, to his companions in India, from Japan [Bungo probably], 20 September 1555, in Matsuda, Hôkokushû 3, 1: 210-12; and Miguel Vaz, to his companions in Japan, from Bungo, 16 September 1566, in Matsuda, Hôkokushû 3, 3: 166; Luis Frois's report on 1583, to the general superior, 2 January 1584, in Matsuda, Hôkokushû 3, 6: 201-02; Luis Frois's report on 1591-1592, to the general superior, 1 October 1592, in Matsuda, Hôkokushû 1, 1: 292-94. 
military lines by giving superiors military titles. The use of the military metaphors would be perfectly natural for a Jesuit. ${ }^{19}$

As the pioneer missionary in Japan, Father Xavier, a contemporary companion of Ignatius Loyola, was the first to refer to the 'demons' in Japan. In 1551, when the mission of Father Torres and Brother Juan Fernández, working in Yamaguchi, was hindered by civil war, Father Xavier ascribed the cause of the warfare to the secret operation of the devil. He also asserted that Shaka and Amida, whom people worshipped, were not men but pure inventions of demons. ${ }^{20}$

Later Jesuits in Japan shared this basic idea of demons. The Jesuits extended the term of demons to almost any non-Christian spirit-like beings opposite to God. The three key phrases they associated with demons were first, worshipped idols; second, non-Christian-or pagan in a Jesuit sense-organisations; and third, spiritual practitioners. First, any non-Christian idols for worship were labelled demons in missionary accounts. For example, not only did Father Frois refer to Amida and Shaka as demons but he extended such appellations to include Kôbôdaishi, the founder of the Tendai Buddhist sect. After enumerating different icons that represented kami, Buddhist statues and popular deities such as beasts and natural products, Father Vilela maintained that the devils were responsible for misleading people to pray to all these allegedly demonised idols. In his explanation, there was no fundamental distinction among various sects of Buddhism and Shintô, and other popular forms of worship because all their objects of worship were commonly manipulated by the devil. ${ }^{21}$

Second, the Jesuits regarded any church-like organisation as a place for demonic activity. Father Frois contended that the Kasuga Shintô

19 Pierre Wolfe (ed.), The Spiritual Excercises of Saint Ignatius (Liguori, Missouri: Triumph, 1997), the fourth day of the second week, notes 136-48, pp. 38-40 \& 145-46.

${ }^{20}$ Francisco de Xavier, to his companions in Europe, from Cochin, 29 January 1552, in Costelloe, op. cit., ep. 96, 337-39, \& in Kôno, ep. 96, 536-39.

${ }^{21}$ Luis Frois, to his companions in China and India, from Kyoto, 20 February 1565, in Matsuda, Hôkokushû 3, 2: 306-10; Gaspar Vilela, to his companions at Avis in Portugal, from Goa, 6 October 1571, in Matsuda, Hôkokushû 3, 4: 148. Father Vilela enumerated ten objects of veneration he described as 'kami', including Benzai, Bishamon, Daikoku, Monju, Fudô, Kannon, Taga Daimyôjin, Yakushi, Marishiten and Hachiman; two Buddhas, Shaka and Amida; as well as seven other popular idols: foxes, snakes, bulls, deers, turtles, trees and stones. This represents an interesting mix of Shintô and Buddhist figures. It must be noted, however, that the syncretic image of Shintô and Buddhism was originally a Japanese tradition. With the spread of Buddhism in Japan, there developed a synchretic idea called 'Honji Suijaku', which showed that the Japanese kami was a form of the appearance, or Suijaku, of Buddha, or Honji. 
shrine in Nara deified a demon, but he did not apparently know that its enshrined deity was the progenitor of the historic Fujiwara clan, which had dominated imperial politics as regents from the ninth to the eleventh centuries. This means that any convert who followed Father Frois's preaching about the Kasuga shrine had to agree that a devil was the ancestor of the noble Fujiwara family. Also, Father Vilela contended that Buddhist temples belonged to demons and that Buddhists adored them. He wrote, in 1571, that all the two hundred Buddhist temples on Mount Atago, ten kilometres west of Kyoto, were, together with the mountain itself, devoted to demons. ${ }^{22}$

Third, the missionaries described as an agent of the devil any nonChristian who claimed that he or she possessed the power to deal with souls or spirits. Besides temple Buddhists, the Jesuits found another type of devil worshipper. In the sixteenth century, the only possible method for ordinary Japanese to cure disease was to exterminate the evil spirit inside the body of a patient with the help of shamans. The Jesuits explained that the shamans were servants of evil spirits, or the devil itself. Yamabushi, or mountain ascetics, were the devil's servants, as far as Fathers Frois and Cabral were concerned. According to them, Yamabushi adored the devil and devoted themselves to demonism. The missionaries stated that these mountain ascetics made a contract with Satan to perform witchcraft and exorcise demons from a human body. ${ }^{23}$ Thus, by blurring fundamental differences among the forms of worship, the Jesuits placed all kinds of Japanese beliefs under the single appellation of demonism or diabolism.

\section{b. The Social Structure}

The social structure of the Japanese was of further cultural interest to the Jesuits. Their European or Christian perspective helped the missionaries to understand Japanese feudal society. Their key words were power and authority, which came empirically from feudalism and

${ }^{22}$ Luis Frois, to his companions in China and India, from Kyoto, 20 February 1565, in Matsuda, Hôkokush û 3, 2: 306-10; Gaspar Vilela, to his companions at Avis in Portugal, from Goa, 6 October 1571, in Matsuda, Hôkokushû 3, 4: 134-35.

${ }^{23}$ Luis Frois, to his companions in China and India, from Kyoto, 20 February 1565, in Matsuda, Hôkokush û 3, 2: 306-10; Francisco Cabral, to his companions in Portugal, from Kuchinotsu, 9 September 1576, in Matsuda, Hôkokush û 3, 4: 285-86; Luis Frois, from Kuchinotsu, 13 February 1583 (the recipient is missing), in Matsuda, Hôkokushû 3, 6: 161-63. 
theocracy in Europe. Despite the differences between the European and Japanese feudal societies, the Jesuit interpretation of Japanese society, with a focus upon these two words, worked well in negotiations with the political authorities. Their accounts are partly on the subject of political negotiations with local and central rulers. For example, upon arriving in Japan, Father Xavier intended to meet the Japanese Emperor in Kyoto, a meeting that, as it turned out, never took place. ${ }^{24}$ The local Ômura, Arima and Ôtomo clans in Kyushu were always referred to as pro-Christian patrons in other reports. The correspondence from the Kansai regions in the third quarter of the sixteenth century often describes the missionary efforts at gaining the patronage of powerful warrior lords like Oda Nobunaga and his successor Toyotomi Hideyoshi. ${ }^{25}$

The Jesuits tried to make an analogy with power structures in Europe and studied the Japanese structure of power and authority to figure out the best evangelistic approach. In 1561, Father Torres pointed to three kinds of rulers. The first kind was the top priest of the Buddhist hierarchy, whom he considered to be a spiritual head. The second was the Emperor, whom he regarded as an honorary secular authority. Torres enumerated the nobility in Kyoto as the third kind of ruler. In his interpretation, this nobility had the political power and was in charge of the judiciary and administration. ${ }^{26}$

Father Frois amended this interpretation by referring to two kings. One was a king of power and political authority, or kôbôsama. He was probably referring to the shogunate, which enjoyed a degree of political authority but had lost administrative power in the civil war of the fifteenth and sixteenth centuries. The other was a king with spiritual authority, the Emperor. While Father Torres initially considered the Emperor to be a secular authority, later Father Frois corrected his idea and described the Emperor as a king of spiritual authority. ${ }^{27}$

In 1583, Father Valignano summarised Jesuit knowledge of the Japanese hierarchy in his confidential report to General Superior

${ }^{24}$ Francisco de Xavier, to his companions living in Goa, from Kagoshima, 5 November 1549; Francisco de Xavier, to his companions in Europe, from Cochin, 29 January 1552, in Costelloe, op. cit., ep. 90 \& 96, $310 \& 332$.

${ }^{25}$ This approach of winning over social leaders first was generally a standard Jesuit approach, not peculiar to the missionaries in Japan.

${ }^{26}$ Cosme de Torres, to Father Antonio de Quadros, superior of India, from Bungo, 8 october 1561, in Matsuda, Hôkokushû 3, 1: 338-40.

${ }^{27}$ Luis Frois, to his companions in China and India, from Kyoto, 20 February 1565, in Matsuda, Hôkokush û 3, 2: 306. 
Claudio Aquaviva in Rome. He pointed to the Japanese type of seigneurial system based on the redistribution of estates, in which a daimyô had absolute power over the lives and property of his retainers. He also divided Japanese feudal society into five social strata, which included first, daimyô as the top class; second, bonzes, or Buddhist priests; third, warriors; fourth, merchants and artisans; and last, at the bottom, peasants and servants. ${ }^{28}$

Father Frois's letter of 1569 represents the most perceptive account of this social hierarchy. He proposed that the missionaries should first gain the patronage of national or domain rulers and then use their favour and appreciation for Christian priests to achieve success among the nobility and populace. ${ }^{29}$ The limitation of these missionary analyses, however, was due to the fact that the priests were unable to understand the source of Japanese power and authority, which was derived from the creators of the Japanese islands in ancient mythology.

\section{Jesuit Biases}

Jesuit interpretations of Japanese culture were influenced by a combination of wilful descriptive manipulations and Euro-Christian biases. The intention of a correspondent sometimes determined which piece of information he would emphasise in his letter. It also determined how he would present his observations, either negatively or positively. Moreover, the cultural observations about non-Christian objects were influenced by interpretive biases. The European and Christian origins made the missionaries interpret the physical experience within the context of their own common sense. In viewing the opponents' or potential converts' physical appearances and characteristics, the Jesuits were unable to escape from their own European cultural values. They saw, for example, any non-Christian spiritual idols to be an unacceptable pagan symbol.

Jesuit biases also influenced the second-hand information gleaned from their native informants, and the biases were most conspicuous in the comprehension of Japanese beliefs and social structures. The Jesuits relied on a Christian framework of religion in order to interpret

${ }^{28}$ Alejandro Valignano, S. I., Sumario de las cosas de Japón (1583). The text used in this study is Matsuda Kiichi et al. (eds.), Nippon junsatuki (Tokyo: Heibon-sha, 1973), 6-8.

29 Luis Frois, to Father Belchior de Figuereido, from Kyoto, 12 July 1569, in Matsuda, Hôkokushû 3, 3: 341-42. 
Buddhism, Shintô, and other beliefs. Although they were aware that Japanese spirituality was different from Christianity, they still relied on basic Christian concepts to understand different Japanese customs within an assumed unity of the Japanese 'religion'. Consequently what they described conveniently as the Japanese 'religion' was a demonic synthesis of all non-Christian spiritualities that accurately represented neither Buddhism nor Shintô nor any other belief. In their understanding of the social structure, the Jesuits focussed on how to take advantage of it for a successful mission, but their study of the social structure did not help the missionaries to understand the Japanese spirituality that lay behind it.

There is, nevertheless, one fact that has to be borne in mind when discussing the biases of missionary accounts-that is the identity of the anticipated readers of each report. All the readers would be European brethren and supporters, who had no knowledge of Japan. The Jesuit correspondents were responsible for describing their experiences and observations as comprehensibly as possible. The readers would naturally understand the reports in a European language and with familiar references to European culture. That is how the missionaries had to communicate with the European readers no matter how accurately and truthfully the priests analysed the non-Christian nation. This necessary, rhetorical compromise is likely to have further exacerbated the interpretive biases, which may have been smaller in the minds of the Jesuits working in the archipelago. Therefore, the actual Jesuit biases need to be discounted to some extent.

\section{Propositions for New France}

The Iberian mission to Japan presents two proposed ideas for considering the French case in North America. The first idea is that the situations of the missionaries at each developmental stage of the mission generally determined the interpretations or the descriptions of non-Christian culture. However personal the written observations may appear to be, the thematic and interpretive descriptions were influenced more by the interests of the Jesuit religious order than by personal initiatives.

The second idea is that the biases that affected the cross-cultural understanding of Japan were not peculiar to the Iberian Jesuits. For discussing the missionary interpretations of non-Christian cultures in this respect, it is not important to examine how often or how seldom 
the French missionaries read the Japan reports; in short, the issue is not to determine how carefully the Jesuits read the accounts of Japan in French or in other languages. The French missionaries did not recognise that they might be repeating the same erroneous analysis that their Iberian predecessors had made in their established style of reports, because they were unable to learn from the Iberian mistakes. Admittedly there may have been differences in time and in origins between the sixteenth-century Iberian Jesuits and the seventeenth-century French Jesuits. ${ }^{30}$ Yet this kind of difference was minimal compared with the vast cultural differences between European perspectives and Japanese or Amerindian ones.

In the established rhetoric of the Jesuit reports, the seventeenthcentury French missionaries made an epistemological misjudgement similar to that of the sixteenth-century Iberian missionaries, since European readers in those centuries lacked an entirely non-Christian perspective that may have helped them to identify the Iberian misunderstandings. So long as the missionaries corresponded with the readers both in a European language and according to the Euro-Christian cultural value systems, their written accounts were ruled by European or Christian biases. These two identifications of biases will thus shed light on the French interpretations of Amerindian culture.

\section{B. The French Jesuit Interpretation of Native Culture}

From a contemporary seventeenth-century standpoint, Jesuit missionaries were masters of Euro-Christian knowledge and thus as capable of understanding non-Christian cultures as were any other European. The problem was they were able to do so only in their own systematic way. When approaching potential converts, the European missionaries

\footnotetext{
${ }^{30}$ For example, northern Europeans were affected by a witch-hunting mania in the 1600 s, and this would have affected the priests' view of alien spiritual beliefs. Also, there were all sorts of differences among people who did not follow the Roman Catholic Church. In addition to Christians who continued to believe in the old popular religions, there were Muslim descendents in Portugal and Spain while Protestants were making inroads in France in the sixteenth century. Until Spain conquered the Islamic kingdom of Granada in 1492 for the completion of the Reconquista, the Iberian Peninsula had been a place for Muslim residents ruled by the Nasrid dynasty. See, for example, William A. Christian, Local Religion in Sixteenth-Century Spain (Princeton, NJ: Princeton UP, 1981); and L. P. Harvey, Muslims in Spain, 1500 to 1614 (Chicago \& London: University of Chicago Press, 2005).
} 
encountered a wide gap between Christian and non-Christian cultures. Within the confines of early-modern western intellectual concepts, their analysis, albeit biased, was the best available at the time. Historians today, however, agree that the missionary interpretation of Amerindians is biased enough to be treated with caution.

The problem is that few authors have ever substantially identified the exact nature of the European and Christian biases that ruled seventeenthcentury missionaries. In Les Hurons-Wendats, for example, Georges E. Sioui implies that Jesuit comments on the indigenous people are not only culturally and religiously biased but also contemptuous, scoffing, or indifferent. ${ }^{31}$ Sioui, who claims to be of Wendat descent, frequently cites The Jesuit Relations for sustaining his ideas about an aboriginal heritage, but his lengthy monograph fails to illustrate how and where Jesuit accounts are biased. Also, Carole Blackburn, in Harvest of Souls, argues that the Relations are unreliable because the missionary descriptions of autochthonous customs are distorted. ${ }^{32}$ She is silent, however, when it comes to providing the reader with a concrete example of what she calls unreliability and distortions.

Some of the rare attempts to specify Jesuit biases can be found in the works of Elizabeth Tooker and Bruce G. Trigger. Tooker maintains that the missionaries had obvious biases in their observations of Amerindians, but she only gives one example, that is the missionary tendency to see demonism in native beliefs. Trigger focusses on thematic biases. The Jesuit attempts to analyse native culture, he contends, were pragmatic, and directed towards winning converts to Christianity. He affirms that the missionaries felt obliged to take note only of law, government and religion, which were vital in their dealings with indigenous people. Trigger also argues that the missionaries considered it unnecessary to write about other aspects, such as the kinship system, subsistence activities, trade and warfare. As for the biases of interpretations, his concerns are merely with the possible alterations

31 Georges E. Sioui, Les Hurons-Wendats: Une civilisation méconnue (Sainte-Foy, Québec: Les Presses de l'Université Laval, 1994), 264; Sioui, Huron-Wendat: The Heritage of the Circle (Vancouver \& Toronto: University of British Columbia Press; \& East Lansing: Michigan State University Press, 1999), 136.

32 Carole Blackburn, Harvest of Souls (Montreal \& Kingston: McGill-Queen's University Press, 2000), 4-5. 
during the editorial process, including the mutilations or poor copies of manuscripts and the distortions of original meanings. ${ }^{33}$

However biased, the French Jesuits attempted a thorough observation of their evangelistic subjects as did the Iberian missionaries. The Jesuits who experienced Amerindian culture landed first in Acadia in the 1610s, following which they established a base in Quebec in 1625. As in the Iberian case, their biases are evident in two basic categories, direct or first-hand observations and indirect or second-hand observations, although such a distinction is not entirely clear in some descriptions.

\section{First-hand Observations}

Fathers Pierre Biard and Énemond Massé were the Jesuit pioneers in North America, but their situation was different from Father Xavier's. These two Fathers were not pioneer missionaries in French North America, because Father Jessé Fléché, a priest of the diocese of Langre, had been there for a year when they arrived in Acadia in 1611. This complex factional situation seems to have coloured the Jesuit observation of the Mi'kmaq and the Maliseet, the native peoples in Acadia, just as the Iberian descriptions of the Japanese as potential Christian converts were adjusted, depending on the intention of the reporter.

The initial Jesuit task in their correspondence was to criticise the effort of Father Fléché. Father Biard commented harshly on the five native converts, seemingly healthy adults, who had been baptised by their missionary predecessor. According to the Jesuit father, these native converts at Port Saint John did not understand his question as to whether or not they were Christians. When they were asked alternatively whether they were baptised, the very best they could answer was that the patriarch had made them like Normans. Father Biard therefore asserted that there was no genuine conversion before the Jesuits arrived, and that the indigenous people were just as savage as they had been even after their alleged conversions by Father Fléché. ${ }^{34}$

${ }^{33}$ Elizabeth Tooker, An Ethnography of the Huron Indians, 1615-1649 (1964, Syracuse: Syracuse University Press, 1991), 07; and Bruce G. Trigger, The Huron (New York: Holt, 1969), 4-5; Bruce G. Trigger, The Children of Aataentsic (Kingston \& Montreal: McGill-Queen's University Press, 1976), 17.

${ }^{34}$ Pierre Biard, to Father Christophe Baltazar, provincial of France at Paris, from Port Royal, 10 June 1611, in Reuben Gold Thwaites et al. (eds.), The Jesuit Relations 
Unlike Father Xavier, who had to justify his own choice of the Japanese as missionary objects, the Jesuits in Acadia were under no obligation to describe the Amerindian population in a positive way. Father Biard's direct observations of the Amerindians as potential Christians were thus simply negative. In his account of 1611, the nation was 'savage', 'or sauvage', which meant uncivilised, and the 'savage' people were full of bad habits. The people were haunting the woods, ignorant, lawless and rude. Given to any kind of lewdness, they were also vengeful, lazy, gluttonous, profane and treacherous. They were vainglorious because they believed themselves to be more valiant, more ingenious and wealthier than the French. In the Relation, or the annual report, of the years 1613 and 1614, whose authorship may be either Father Biard or Father Massé, the tone becomes even more scornful. The people were united by no mutual interests, possessing no arts, and indolent in every occupation. On the whole, they were considered to be hardly above the beasts. ${ }^{35}$

The negative tone disappears in the Relation of 1616, three years after the armed English colonists drove the Jesuits out of Acadia. After a few years of missionary work, the Jesuit attitude changed to one of justification of their own activity. Perhaps in the hope of resuming the Acadian mission, Father Biard, then in Paris, finally attempted to justify the indigenous people as an appropriate missionary object. He now called the people 'our Savages', or 'nos Sauvages', a term that implied possessiveness of spirit, with little malice, as if to say that 'nos Sauvages', though happy, could be improved by Christian salvation. Also, their physical appearance was handsome and well shaped, which, like the light skin colour of the Japanese, made them appear to be good candidates for Christian conversion. ${ }^{36}$

A similar bias is detected in the observation of the historical Montagnais, now called 'Innu', belonging to the East Algonquian language group. ${ }^{37}$ In 1625, three Jesuit missionaries joined the Récollet Franciscans, who had been ministering in the settlement of Quebec

and Allied Documents (Cleveland, OH: Burrows Brothers, 1896-1901), vol. 1, 163-65 [henceforth, Relations 1: 163-65].

35 Ibid., in Relations 1: 173; and Relatio rerum gestarum in Novo-Francica missione, annis 1613 \& 1614, in Relations 2: 201.

${ }_{36}$ Pierre Biard's Relation of 1616, from Paris, in Relations 3: 73-75.

37 The East Algonquian people maintained their hunting and gathering culture. They included the Algonquin, Mi'kmaq, Maliseet, Innu and Ojibwa. For the relationship between the name of 'Montagnais' and that of 'Innu', see Paul Charest, 'Les 
since 1615. In 1632, after an interruption in their activity caused by the English rule of Quebec from 1629 to 1632, the Jesuits alone returned to New France, and among them was Father Paul le Jeune, the superior of New France. The initial Jesuit observations of the Innu were pessimistic. The expressions Fathers Charles Lalemant and Le Jeune applied to them included naked, beggars, licentious, lazy, rude, incapable of comprehension, fickle, capricious, polygamous, dirty in diet, vermin eaters, given to treachery in war, and cannibalistic or cruel to enemies. $^{38}$

The disdain of the Jesuits decreased drastically in the later account of Father Le Jeune, who camped out with an Innu band during the winter of 1633-1634. After some missionary experience with Innu traders at Quebec, he decided to learn more about this people by actually living with them. Once he tried to include the Innu within the missionary flock of lost sheep, he also altered his assessment of them as missionary subjects. Father Le Jeune's Relation of 1634 uses such positive words as tall, erect, strong, well proportioned, and agile, with no effeminate characteristics. He also described the 'savages', probably with the Innu mainly in mind, as having a good quality of mind, for they have wellformed bodies and well-regulated organs. He expounded that their savage condition was only caused by the lack of education and instruction. He even admired their generosity by pointing to the absence of orphans among them. This was a dramatic change in attitude because he never wrote well of them throughout his Relation of 1632. The most positive thing he said about them there was that they had good minds, in spite of their barbarity and lack of formal education. ${ }^{39}$

As for the Hurons, who belonged to the Iroquoian language group ${ }^{40}$ the situation was somewhat different. The semi-sedentary Hurons were important trade partners of the French ever since the establishment of Quebec. Their country near Lake Simcoe and Georgian Bay

Montagnais d'autrefois, les Innus d'aujourd'hui' in Cap-aux-Diamants 85 (printemps, 2006): 10-15.

${ }^{38}$ Charles Lalemant, to Jérôme Lalemant, from Quebec, 1st August 1626, in Relations 4: 197-99, 219; and Paul le Jeune's Relation of 1632, in Relations 5: 23-29, 53 \& 137. The cited descriptions may also refer to Huron traders who commuted annually to Quebec.

${ }_{39}$ Paul le Jeune's Relation of 1634, in Relations 6: 229-31 \& 239; and Le Jeune's Relation of 1632, in Relations 5: 31-35.

${ }^{40}$ The Iroquoians formed semi-sedentary farming societies. They included the Huron confederacy, later called Wendat, and the Iroquois nations. 
had been a missionary target since the arrival of the Franciscans in 1615. Because of the delayed participation of the Jesuits in the Quebec mission, Fathers Jean de Brébeuf and Anne de Nouë joined the Franciscans among the Hurons in 1626. The English occupation of Quebec from 1629 to 1632 also delayed a Jesuit report on the Huron nation. When Father Brébeuf finally had an opportunity to comment on the Hurons in 1635, the mission had been undertaken for two decades.

Given the existence of the Huron mission, Father Brébeuf s only option for his comments was justification of the Hurons as potential Christian converts. In the Relation of 1635 , he made positive comments about the Hurons to show the ease of converting them to Christianity. He pointed to their peaceful and flexible minds, which he found agreeable to Christian faith and law, besides their horticultural customs. As far as he was concerned, their vices and superstitions were due to minds that were untrained and untamed by Jesuit teaching. ${ }^{41}$

Father Brébeuf's observations contrast with the comment by Father Le Jeune, who was not in charge of the Huron mission and knew the Hurons merely as traders visiting Quebec. Father Le Jeune's negative comments on the Innu, who were 'sauvages', do not refer specifically to a single tribe, and refer to Huron traders also. In addition, he introduced them to the reader as skilled thieves who, he guessed, tried to show their intelligence through thefts. ${ }^{42}$

The above three cases of Acadia and the Saint Lawrence, along with the case of Father Xavier in Japan, indicate two intertwined aspects that influenced the French Jesuit observations of the indigenous peoples. They were, first, the value of the native people's importance as a missionary object and, second, or furthermore, the possibility for the successful evangelistic activity among them. When an observer, whether Iberian or French, commented on his missionary objects, he always tried to find some reason to expect them to accept Christianity. All priests, whether Iberian or French, always lived in hope of converting the non-Christian people. In the Iberian reports, the belligerent and avaricious Japanese in some accounts became the best-qualified candidates for Christianity in others. In the accounts of New France

${ }^{41}$ Jean de Brébeufs Relation of 1635, in Relations 8: 151-53; Lucien Campeau (ed.), Monumenta Novae Franciae (Roma: Monumenta Historica Soc. Iesu; Québec: \& Montréal: Bellarmin; or Québec: Les Presses de l'Université Laval, 1967-2003), vol. 3 (1987), 114-15 [henceforth, Campeau, Monumenta, 3: 114-15].

${ }^{42}$ Paul le Jeune's Relation of 1633, in Relations 5: 241-43. 
also, the Amerindians were no different from wild beasts when regarded as unsuited for missionary activity. Yet they were described as good-natured people with docile minds once counted as potential converts. When recording observations of the indigenous people, the priests wrote implicitly of their missionary plan in a new land rather than of their objective ideas of the Amerindians' genuine character.

\section{Second-hand Observations}

Just as with the direct observations, the indirect observations based on the information obtained from their Amerindian informants were also not free of biases. Despite the difference of locations, the main themes for the second-hand observations had not changed since the time of the Jesuit pioneer Francisco de Xavier. The French missionaries' written concerns were with the non-Christian religion and social structure. These were the two aspects of culture they investigated in order to replace paganism with Christianity and to win the support of native society as well.

\section{a. Non-Christian Worship}

The non-Christian religion, to begin with, was a primary theme in the Jesuit accounts of native culture, just as Japanese spirituality was in the Iberian accounts. This conceptual framework has not been revised substantially even in most of the twentieth-and twenty-first-century academic publications, except in The Huron by Trigger. ${ }^{43}$ Back in 1626, after failing to detect native religion, Father Charles Lalemant pointed to the lack of any institutional form of divine worship. Similarly Father Le Jeune asserted, in 1632, that the Amerindian people knew little religion if any, let alone the worship of any particular divinity. In 1635, Father Le Jeune more confidently noted that the people were devoid of

\footnotetext{
${ }^{43}$ Trigger, op. cit., 90-93. Although he deals with collective beliefs rather than religion in this work, native religion is the common framework of many other influential publications. See, for example, Alfred Goldsworthy Bailey, The Conflict of European and Eastern Algonkian Cultures, 1504-1700 (1937, second ed., Toronto \& Buffalo: University of Toronto Presss, 1969), 126-47; W. Vernon Kinietz, The Indians of the Western Great Lakes, 1615-1760 (1940, n.p.: Ann Arbor, 1965), 122-60; Tooker, op. cit., 72-121; Lucien Campeau, La mission des Jésuites chez les Hurons, 16341650 (Montréal: Bellarmin; \& Rome: Institute Historicum S. I., 1987), 97-112; and Shenwen Li, Stratégies missionnaires des jésuites français en Nouvelle-France et en Chine au XVII siècle (Saint-Nicolas, Québec: les Presses de l'Université Laval; \& Paris: Harmattan, 2001), 61-75.
} 
any religious notions. As late as 1710, Father Joseph Jouvency reviewed the Jesuit activity of the previous century and affirmed that there was 'no system' of religion in the native culture. ${ }^{44}$

This French denial of native religion is reminiscent of the Iberian priests' failed attempts to detect traces of the Apostle Thomas's Christianity in Japan. ${ }^{45}$ In each case, the missionaries refused to equate nonChristian customs with formal religion, since they were too rigid to go beyond the existing Christian framework of religion. The Jesuits initially believed that the First Nations had neither religion nor divine worship. Thus, one might assume that the missionaries interpreted native beliefs within a conceptual framework based on the Christian religion and divine worship. It is necessary to examine whether the French Jesuits made the same mistake as their Iberian predecessors, who reconstructed various Japanese beliefs into a single framework, which they thought logical, but which turned out to be rather chaotic.

Despite the initial denial of a native religion's existence, the French Jesuits employed basic Christian notions to understand the equivalents within Amerindian spirituality, just as did the Iberian missionaries. For example, the missionaries began their research with a presupposition that there should be some pagan idol for worship, since they assumed that Amerindians were pagans. Father Biard's report of 1616 shows his earnest attempt to find a native deity, which he managed to identify as the sun. According to him, the people in Acadia claimed that they believed in a god, but he was sceptical because they knew no prayers or any form of worship except for admiration of Niscaminou, the name of the sun.

The evangelists, however, did not remain as uncomprehending or as intolerant as Father Biard. The shift of interpretations about Amerindian ideas indicates that their observations improved towards the midseventeenth century. In 1626, Father Charles Lalemant identified the sun as an object for some native prayers although he maintained that

${ }^{44}$ Charles Lalemant to Jérôme Lalemant, from Quebec 1st August 1626, in Relations 4: 201-03; Paul le Jeune's Relation of 1632, in Relations 5: 33-35; Le Jeune's Relation of 1635, in Relations 8: 185; and Josepho Juvencio, SJ, De regione et moribus Canadensium seu barbarorum Novae Franciae (Rome: Ex Typographia Georgii Plachi, 1710), edited in Relations 1: 239-98, see esp. 287-89.

${ }_{45}$ The influence of the Apostle Thomas's Christianity has not been confirmed in the history of Japan. Most probably Christianity was not imported to Japan before the Jesuit mission. See for example, Takao Abé, 'The Seventeenth-Century Jesuit Missionary Reports on Hokkaido', Journal of Asian History 39 (2005): 111-28. 
the indigenous people knew no authentic prayers like the ones represented at the Christian church. Father Brébeuf explained, in 1636, that the Hurons addressed themselves to some demon that resided in the earth, rivers, lakes, and above all, the sky. They also worshipped rocks. On their way to Quebec, Father Brébeuf noticed that the Huron traders revered an enormous rock. According to legend, the rock had once been a man. Father Brébeuf also noted that they would seek recourse to the sky in order to obtain daily necessities. He noted the native respect for the great divine bodies in the sky. ${ }^{46}$

When interpreting worshipped objects, the Jesuits also searched for a native god, which they somehow assumed to be the native Creator. Father Le Jeune, in 1632, referred to the Creator and the restorer of all things, whose Algonquian names were Atahocan, or Atachocam, and Messsou. He maintained that this Creator implied some idea of a god. Later in 1634, he added Nipinouskhé and Pipounoukhe, who brought the seasons, as well as Khichikouai, who taught men where to hunt game. And yet he failed to find any hint of veneration in the way that the indigenous people treated these 'gods'. In the case of the Hurons, Father Brébeuf attempted to understand how the indigenous people saw their gods by citing the fables of their origin. To the reader in France, he introduced a Huron version of the Creation story, with a focus on Aataentsic, her unnamed husband and their two boys called Tawiscaron and Iouskeha, or Jouskeha. According to him, while travelling in Heaven to find some healing fruit for her ill husband, Aataentsic fell from Heaven onto a giant Turtle on the earth and brought forth two boys, and these three people created all the creatures on the land and in the water. This Aataentsic was the moon and Iouskeha was the sun. $^{47}$

Accordingly the Creation story became another notion by which the Jesuits attempted to understand native culture. Father Brébeuf's account of Aataentsic and other Creators, cited above, shows his attempt to learn about the Huron idea about Creation. He also tried to learn who created Heaven and earth, but was unable to elicit any

${ }^{46}$ Pierre Biard's Relation of 1616, in Relations 3: 133-35; Charles Lalemant, to Jérôme Lalemant, 1 August 1626, in Relations 4: 203; and Jean de Brébeuf s Relation of the Huons of 1636, in Relations 10: 159-61 \& 165.

${ }_{47}$ Paul le Jeune's Relation of 1632, in Relations 5: 151-57; Le Jeune' Relation of 1634, in Relations 6: 157-59 \& 173; and Brébeuf's Relation of the Hurons of 1636, in Relations 10: 127-139. 
concrete idea from his Huron informants. Fathers Brébeuf and Le Jeune both explained that the Algonquin and Huron peoples believed in the great turtle that held up the earth at the time of Creation. Both priests, however, clearly recognised that the native Creation myth was a fable with no religious overtones. ${ }^{48}$ The native Creator was not in the least an object for religious worship. Their reference to the native Creation myth was thus mainly to show their effort and solution for expounding the Christian idea of the Creation in a way comprehensible to non-Christian people. It may be an inappropriate historical interpretation to describe this world-construction fable as the main element for Jesuit comprehension of the Amerindian religion as do W. Vernon Kinietz and Lucien Campeau, who has apparently accepted the seventeenth-century missionaries' rhetorical paradigm of religion as the universal framework that is even now applied to Amerindian spirituality. ${ }^{49}$

To understand Amerindian spirituality, the Jesuits had recourse to the Amerindian ideas about the immortality of the soul, both in Acadia and in the Saint Lawrence. Their focus, however, seems to have been on whether irreligious Amerindians were capable of understanding the Christian notion of the soul, just as the Iberian Jesuits confirmed the Japanese recognition of the soul through the Buddhist belief in an afterlife. Father Biard's Relation of 1616 suggests that he tried to find out whether or not they understood the idea of a soul. His conclusion was that the native idea of the soul existed but that they were not clear about the soul's immortality and about the future reward and punishment to the soul. Father Charles Lalemant in Quebec seems to have made the same attempt in 1626, even though he wrote instead that the Amerindians believed in the immortality of souls. ${ }^{50}$

The native idea of the soul was beyond the understanding of French missionaries. According to Father Charles Lalemant in 1626 and Father Le Jeune in 1637, the Algonquin imagined that, in the other

48 Jean de Brébeuf Relation of the Hurons of 1635, in Relations 8: 147; Brébeuf's Relation of the Hurons of 1636, in Relations 10: 129; and Paul le Jeune's Relation of 1637, in Relations 12: 73-75.

${ }^{49}$ W. Vernon Kinietz, op. cit., 122-23; and Lucien Campeau, op. cit., 106-08. Others like Elizabeth Tooker and George E. Sioui are more cautious in dealing with the Huron idea of Creation and discuss it in the category of myths. See Tooker, op. cit., 145-48; and Sioui, op. cit., 16-19.

${ }^{50}$ Pierre Biard's Relation of 1616, in Relations 3: 133-35; and Charles Lalemant, to Jérôme Lalemant, 1 August 1626, in Relations 4: 201-03. 
world after death, the souls would eat and drink and speak with each other, as did the living. Later, in 1639, Father Le Jeune realised that the people distinguished more than one soul in one body. In the Huron country also, Father Brébeuf retrieved from his informants an indigenous interpretation about the fate, or the destination, of the soul after death. After learning that the destination was somewhere to the west of the earth, he was reportedly astounded to learn of their solid faith in this oral tradition about the soul because the Christian interpretation about it was the only truth, as far as he was concerned. It is possible that what the missionaries depicted as the Amerindian souls was something beyond the soul, or even something else like symbolic and eternal spirits that could shift from one body after death and eventually to another body at birth. ${ }^{51}$

The lack of references to the native idea of births prevented further consideration, however. All the missionaries persisted in the notion of the soul and commonly explained that the contradiction was caused by a superstition or an erroneous idea of the indigenous people. Concentrating too much on the indigenous people's familiarity with the soul, the Jesuits never thought of going outside the Christian paradigm.

Heaven was another convenient clue to identifying the destination of souls after death. In 1626, Father Charles Lalemant learnt that native souls, after death, would go to the other world. His Christian bias helped him to leap to a conclusion that this other world was the same as what Christians called Heaven. Later correspondents, however, did not repeat this interpretation. In 1636, Father Brébeuf noted that the Huron otherworld was somewhere far away on the earth, and thus he did not call it Heaven. Instead, he presented the notion of the sky, which was at least closer to the Christian Heaven. ${ }^{52}$ In truth, the Amerindians did not have a concept of Heaven as the settlement of the virtuous.

As was the case with Iberian missionaries, the conflict between God in Heaven and some rival spirits seems to have ruled the French interpretation of the Amerindian deity. The Jesuits found some supernatural

${ }^{51}$ Charles Lalemant, to Jérôme Lalemant, 1 August 1626, in Relations 4: 201-03; Paul le Jeune's Relation of 1637, in Relations 12: 27-29; Paul le Jeune's Relation of 1639, in Relations 16: 191-93; and Brébeuf's Relation of the Hurons of 1636, in Relations 10: 143-149.

${ }^{52}$ Charles Lalemant, to Jérôme Lalemant, 1 August 1626, in Relations 4: 201-03; and Brébeuf's Relation of the Hurons of 1636, in Relations 10: 143-149 \& 159-61. 
spirit in the native culture. The Algonquian name of the native spirit was 'manitou' while its Huron or Iroquoian name was 'oki' in the singular or 'ondaki' in the plural. Because it was different from a Christian spirit, the Jesuits did not hesitate to call it the devil or a demon. Father Le Jeune first learnt that the Innu people believed it to be an angel or some powerful being which was a source of evil and the cause of illness. He enumerated three kinds of manitou, or demons: first, the originator of disease; second, the cause of death; and third, manitou that presided over war and created the earth. To Father Le Jeune, a Christian, to think that a demon created the earth must have been too difficult and too confusing to understand. Suddenly at this point, his account abandons the devil when referring to this third manitou and instead calls it a god. He questioned his informant as to where this god was before Creation, but the informant was unable to answer any further. Father Le Jeune's category of manitou is limited to the first two kinds later in the same report, and the third kind of manitou as the Creator never reappears in his or other accounts. ${ }^{53}$

The missionaries in the Huron country tried to explain the oki in a way comprehensible to European Christians. Father Brébeuf inferred that his Hurons honoured a demonic divinity called 'oki' or 'ondaki', which they imagined to be in the sky and to control the seasons of the year. Father Paul Ragueneau explained that his Hurons accepted any unnatural or extraordinary happening as a spiritually powerful oki. He also learnt that the native people believed that an oki, or a powerful genie, would enter shamans' bodies or appear in their dreams, and would show them supernatural wonders. In addition, Father Brébeuf recognised that the oki was also used metaphorically, referring to those esteemed individuals who had performed miracles. ${ }^{54}$

The use of an oki as a simplistic synonym for a devil or a demon is found, for example, in the following three Jesuit reports. Father François-Joseph le Mercier called an oki a demon which, according to a Huron charlatan, lived in the house of ondaki under the ground before surfacing. Also, Fathers François du Péron and Jérôme Lalemant

${ }^{53}$ Paul le Jeune's Relation of 1633, in Relations 5: 157; Le Jeune's Relation of 1634, in Relations 6: 175; \& 7: 181-83; and Le Jeune's Relation of 1636, in Relations 9: 81-83, $125-27 \& 209-11$.

${ }^{54}$ Jean de Brébeuf's Relation of the Hurons of 1635, in Relations 8: 99-101; Brébeuf's Relation of the Hurons of 1636, in Relations 10: 49 \& 161; and Paul Raguenau's Relation of the Hurons of 1648, in Relations 33: 193 \& 211. 
simply called this native spirit 'the devil' or 'the demon' who spoke to Hurons in dreams, in the form of a crow, a serpent, other animals, a flame or a ghost. In these forms, recounted Father Lalemant, the demons reportedly revealed the secret of good fortune in the recovery of health or in achieving success in work. Considering all the statements by these six Jesuit correspondents, the native manitou or an oki was something more complex than the devil. In this Jesuit rhetoric, however, there was no other appellation but 'demon' or 'devil' for indicating any non-Christian spirit holding supernatural power, the power that in Christianity was exercised by God. ${ }^{55}$ This was also the case in the Iberian accounts.

In connection with the devil, the Jesuit missionaries paid attention to two aspects of Amerindian culture: native shamans and rituals, such as feasts or ceremonies. These are also reflected in Father Brébeuf's observation of the Huron people, that they had neither temples, nor priests, nor feasts, nor any ceremonies. His statement represents the Jesuit idea about these four necessary religious components. Although the missionaries found no temples among them, they detected native shamans, as the equivalents for priests, and indigenous rituals, as equivalents for feasts and ceremonies.

Just as the Iberian missionaries made frequent references to Buddhist bonzes and Shintô priests, the French missionaries paid critical attention to native shamans. The reporters used a variety of terms, which included sorcerers, soothsayers, jugglers, charlatans, magicians, medicine men, deceivers and ministers of Satan or of Hell. ${ }^{56}$ Their analysis of the rôle of shamans was directed towards interpreting what the people expected and anticipated from the Amerindian spirits that they called demons. According to Father Le Jeune, for example, the Innu believed that their sorcerers could kill people with charms by communicating with manitou. He also referred to an Innu 'juggler'

${ }_{55}$ François-Joseph le Mercier's Relation of the Hurons of 1637, in Relations 13: 105-07; and François du Péron, to Joseph-Imbert du Péron, from Ossossané, 27 April 1639, in Relations 15: 177; and Jérôme Lalemant's Relation of the Hurons of 1639, in Relations 17: 153-55.

${ }_{56}$ Pierre Biard, to the general superior, from Port Royal 31 January 1612, in Relations 2: 75; Paul le Jeune's Relation of 1635, in Relations 8: 123-25; Le Jeune's Relation of 1636, in Relations 8: 273; Jean de Brébeuf's Relation of the Hurons of 1636, in Relations 10: 197; Le Mercier's Relation of the Hurons of 1637, in Relations 13: 105-07; Jérôme Lalemant's Relation of the Hurons of 1639, in Relations 16: 195-97; Lalemant's Relation of 1640, in Relations 19: 83 \& 179; and Paul Ragueneau's Relation of the Hurons of 1648, in Relations 33: 203-07. 
who was believed by his country people to restore the health of the sick by dealing with manitou, only in exchange for treasures like porcelain, beads necklace and beaver pelts. As a faithful reader of accounts of the Japanese mission, Father Le Jeune compared this native shaman scornfully to Japanese bonzes, who claimed the power to lead their wealthy supporters to paradise, or, to be more precise, to the world of Buddha, provided they paid a fortune. Apparently the shaman never provided the same services to the poor. Father Brébeuf, too, noticed that the Huron sorcerers attempted to cure diseases only after having received generous presents and good pay. ${ }^{57}$

The Jesuit interpretations of Huron shamans were more detailed than the interpretations of Innu shamans because of their regular residence in the Huron country, even though missionaries' basic attitude was the same as Father Le Jeune's. Father Brébeuf learnt that there were four kinds of Huron shamans who would perform their duties allegedly with the assistance of native genies. The first kind of shaman was presumed to command the rain and winds. The second kind predicted future events. The third kind tried to find lost objects. And the fourth kind would restore health to the ill. As to the last type of shaman, Father Jérôme Lalemant later distinguished two further kinds: magicians, who determined the nature of diseases and those who give remedies. He also differentiated metaphorically between magicians and sorcerers. According to him, the Hurons distinguished successful shamans from unsuccessful ones by their ability to predict the identity, number and locations of their enemies in war. The former, or magicians, were honoured publicly as angels of light, and the latter, or sorcerers, were abominated as angels of darkness. ${ }^{58}$

Despite all these differences, the Jesuit accounts treat all the shamans commonly as demonic agents allegedly communicating with the devil, as does the Iberian correspondence against the Buddhist and Shintô practitioners in Japan. It is true that the priests' attitude represented their firm belief in monotheism, in which there is only one true God and other supernatural beings must be false or antagonistic. Yet

${ }^{57}$ Paul le Jeune's Relation of 1636, in Relations 8: 271-73; and Le Jeune's Relation of 1637, in Relations 12: 07; and Jean de Brébeuf's Relation of the Hurons of 1635, in Relations 8: 123.

${ }^{58}$ Jean de Brébeuf's Relation of the Hurons of 1636, in Relations 10: 193-95; Jérôme Lalemant's Relation of the Hurons of 1639, in Relations 17: 211-13; and Lalemant's Relation of the Hurons of 1640, in Relations 19: 183. A more detailed description of the Huron shamans is in Kinietz, op. cit., 131-35. 
more significantly the French missionaries repeated the mistakes of the Iberian missionaries, since the Iberian predecessors themselves failed to recognise their epistemological errors and did not admit them in their reports.

Some native rituals were aspects of demonism from a Jesuit perspective. In the Relation of 1636, Father Brébeuf referred to four kinds of Huron feasts: feasts of thanksgiving or gratitude; farewell feasts; feasts for singing and eating; and feasts for deliverance from an illness. Later in the same report, he added the feast of the dead, held every twelve years, in which people confirmed their friendship and harmony. Father Brébeuf gave no detailed explanation for thanksgiving. According to him and other missionaries, farewell feasts were held by a dying individual for his friends and prominent people. Singing feasts were held when a person had performed a notable act, when a person intended to take a new name, and when the people planned to go to war. Father Jérôme Lalemant's interpretation was more controlled by demonism. In his observation of the Neutrals, or the Atiwandaronk, in 1642, he related that most of the feasts were sacrifices to the devil. What the Jesuits most commonly associated with the devil were, however, the feasts or rituals for healing the sick..$^{59}$

To the French missionaries, the native healing ceremonies, which included no European-style medical treatments, represented demonic shamanism, as did the healing activity of Japanese yamabushi to Iberian missionaries. Father Brébeuf referred to a curing feast or chant when his Huron hosts sang to eliminate the demon that had caused a disease. He also recounted two healing games for curing the sick, directed either by a shaman or by a dream. He learnt that the native shamans would perform such rituals as feasts, dances and songs for determining which evil was the cause of disease. As far as Father Lalemant understood, the native dances, feasts and other curing ceremonies were taught by demons. In his written opinion, the dances and feasts for healing the ill and the success of the native social activity always accompanied a desire inspired by a demon. Thus, most feasts

59 Jean de Brébeufs Relation of the Hurons of 1636, in Relations 10: 59-61, 143, 177-81, 265-67 \& 279-303; Le Mercier's Relation of the Hurons of 1638, in Relations 15: 67; Paul Ragueneau's Relation of the Hurons of 1649, in Relations 34: 113; and Jérôme Lalemant's Relation of the Hurons of 1642, in Relations 23: 185-87. The Jesuits also imagined that fornication was inspired by the devil. See, for example, J. Lalemant's Relations of the Hurons of 1642 and 1643, in Relations 23: 63; \& 26: 227-29. 
were considered as sacrifices to the devil. He wrote also that the entire occupation of chiefs was obeying the devil, in presiding over Hellish ceremonies as well as in exhorting young people to dances, feasts, nudity and lewdness. ${ }^{60}$ The difference between these two missionaries is that Father Brébeuf considered most feasts and rituals to be fake or superficial demonism while Father Lalemant did not question their authenticity. ${ }^{61}$

There have been two basic opinions about the Jesuit use of demonology. One is that the Jesuit missionaries were obsessed by demons and attempted to wage war against them, as can be seen in James Axtell's The Invasion Within and Bruce G. Trigger's The Children of Aataentsic. They note that the Jesuits employed a military metaphor to justify their missionary goals and methods, and deal with the missionary observations of demonism as faits accomplis that do not need to be examined. The other is that the Jesuits did not believe in native demonism, as Peter Goddard contends. He maintains that the use of the term 'devil' is the result of the linguistic deficiency of the priests, and that there was no actual demonism in New France.

This discussion, however, has not yet considered the readers in Europe, who were unable to share any physical American experience with the missionaries. From the Christian view that there is only one true God, all other reputed supernatural beings must be false or antiChristian. Thus, the identification of native divinities with demons came naturally to a Christian perspective. Christians believed that evil spirits could take possession of a person and that the removal of these unclean spirits by exorcism was a priestly function.

Although demons most probably existed, outside Christendom, predominantly in the Euro-Christian belief and rhetoric of the missionaries, demonism helped these Jesuit reporters to explain naturebased and non-Christian rituals dealing with evil spirits in a way

${ }^{60}$ Father Lalement's criticism was common to seventeenth-century religious zealots of the Roman Catholic faith, including Jesuit missionaries. They believed that the spirit and the physical desires were in conflict with each other and that the pious had to subjugate the desire for physical comfort and gratification. See Peter Moogk, La Nouvelle France: The Making of French Canada-A Cultural History (East Lansing: Michigan State University Press, 2000), 253-56.

${ }^{61}$ This paragraph is based on Jean de Brébeuf's Relation of the Hurons of 1635, in Relations 8: 123; Brébeuf's Relation of the Hurons of 1636, in Relations 10: 18589; Jérôme Lalemant's Relation of the Hurons of 1639, in Relations 17: 153-55; and Lalemant's Relation of the Hurons of 1642, in Relations 23: 185-87. 
comprehensible to European readers in the pre-scientific seventeenth century. Demonism was not alien to the knowledge of Christians in Europe. Simultaneously they made use of the concept of demonism in order to demonstrate the need for Christian missionaries who, in the name of God, would combat the devil in New France. ${ }^{62}$ This Ignatian military metaphor was the same with the Iberian references to demonism in Japan.

\section{b. The Social Structure}

The Amerindian social structure, especially of the Huron, Innu and Algonquin peoples, was as important a theme as their spirituality. As in Japan, power and authority seem to have been the basic ways for the Jesuit analysis in New France. Whether in Japan or in New France, or even in other colonies probably, the believers in authoritarianism tended to seek out leadership and attempt to influence most societies through those leaders. The frequent references to native headmen and councils were made from this perspective. The names of native chiefs included, for example, Membertou, a Mi'kmaq chief mentioned by Father Biard; Makheabichtichiou, an Algonquin chief mentioned by Father Le Jeune; and Aenons and Anenkhiondic, Huron chiefs referred to by Father Brébeuf..$^{63}$ Among them, the description of Huron headmen was the most detailed, for the Huron mission was the first mission established in native country well to the west of the French settlements along the Saint Lawrence during the first half of the seventeenth century.

Through an analysis of the Huron chiefs, the Jesuits seem to have tried to figure out whom to approach or where to find influential authority. Father Brébeuf paid special attention to the old men in a village, who determined all matters and advised their people on how to do everything. He also recognised two kinds of chiefs. One kind was a war chief. The other kind was a sachem in charge of the affairs of state,

62 James Axtell, The Invasion Within (New York \& Oxford: Oxford University Press, 1985), 91-94; Trigger, The Children of Aataentsic, 503; and Peter A. Goddard, 'The Devil in New France: Jesuit Demology, 1611-50', in The Canadian Historical Review 78 (1997): 40-62.

${ }^{63}$ Pierre Biard, to Christphe Baltazar, provincial of France, in Paris, from Port Royal, 10 June 1611, in Relations 1: 155, 165 \& 177; Paul le Jeune's Relation of 1637, in Relations 11: 149-83 \& 241; and Jean de Brébeuf's Relation of the Hurons of 1636, in Relations 10: 231, 235 \& 303. 
such as feasts, dances, games, lacrosse matches and funeral ceremonies. There were as many kinds of chiefs as of tribal affairs. Certain chiefs held their pre-eminence because of their intellectual superiority, popularity, wealth, eloquence, generosity, courage and wise conduct. Father Jérôme Lalemant learnt in 1639 and 1642 that chiefs were responsible for making announcements and managing ceremonials, which included dances, feasts and other performances. ${ }^{64}$

The Jesuit reporters also referred to councils, in which they seem to have tried to locate power. According to Father Brébeuf, power was manifested in the chiefs house where the council was held. Father Le Mercier noted, for example, that the council of war was held in the house of the war chief, and the council for the affairs of the country or the observance of law and order was held in the council house, which was probably the civil chief's dwelling. Yet the missionaries recognised that the village government was a civil one and had only partial power over people. The chiefs did not govern their subjects by means of command and absolute power, nor had they any force at hand to compel people to their duty. The council's rôle was instead to represent what was to be done for the good of the village or of the entire country. ${ }^{65}$

\section{Jesuit Biases in Interpreting Non-Christian Cultures}

Of course European priests were not the only people who were influenced by their own culture and religion. Yet in a comparative consideration of Iberian and French Jesuits, it seems clear that the Jesuits in New France described native culture in their own ideological way. The biases of the European missionary correspondents are difficult to identify within the Canadian historical framework based solely on the reading of colonial French missionary accounts. First, the Jesuit observations and interpretations of non-Christian peoples are more restricted and distorted by a wilful manipulation of information as well as by the limitation of their cultural scope. The written observations represent what image and idea the missionaries wished their readers

\footnotetext{
${ }^{64}$ Jean de Brébeufs Relation of the Hurons of 1636, in Relations 10: 15, 229-31; Jérôme Lalemant's Relation of the Hurons of 1639, in Relations 17: 129; and Lalemant's Relation of the Hurons of 1642, in Relations 23: 185.

${ }^{65}$ Jean de Brébeuf's Relation of the Hurons of 1636, in Relations 10: 233-35 \& 261-63; and Le Mercier's Relation of the Hurons of 1637, in Relations 13: 59.
} 
to hold about the indigenous people and their culture, and not what they actually were. The Jesuit annalists manipulated their observations of Amerindians for many possible reasons. For example, they seem to have used the correspondence to criticise other missionary groups that preceded them. For this purpose, native people with whom non-Jesuit missions had dealt were depicted as too barbaric to appreciate Christianity. The Relations were also tools for justifying their choice of missionary subjects, who were described as superstitious and thus needing Christian education. When placed within the range of Jesuit activity, those people who had once been barbarians under another missionary order were deemed to be qualified for Christian instruction.

The Euro-Christian cultural framework employed for interpreting native culture was first restricted by the cultural framework of priests, and then further distorted by the personal priorities of reporters. The missionaries interpreted Amerindian culture from within a EuroChristian value system. What they, as Christians, could not accept was elucidated negatively, and what they intended to accept as a potential hint for becoming Christian was recounted positively.

Second, the Euro-Christian biases and the observational or interpretive mistakes can be attributed to the missionaries' failure to understand the native culture in a native way, and in their misconception that they understood it well. The Iberian experience in Japan helps to affirm that the French missionaries relied heavily on their own existing cultural framework to understand foreign customs, especially beliefs. Even though they were aware that the native beliefs were myth and superstitions rather than religion, the Jesuits still employed Euro-Christian religious concepts in interpreting them. Whenever they could not understand the spiritual custom, they supplemented the mystery with superstitions and demonism as the easiest explanation.

The Jesuits were diplomatic enough to search for power and authority. These two aspects were important for them to find their potential patrons and to figure out whom to approach first. The Jesuit reports on Japan and New France are full of accounts of negotiations with influential men. Their analysis of the Amerindian social structure was directed pragmatically towards this strategic end. The priorities of the French Jesuits therefore limited missionary interpretations. For example, they did not explain why native authority and power were less effective than they needed them to be for spreading Christianity.

Considering both Iberian and French correspondents, however, the Jesuit reporters seem to have adjusted their expressed impressions 
according to the cultural and linguistic comprehension of the readers in their home country. When the priests wrote of their experience, they had to decide what to mention and how to describe it. What the evangelists saw and learnt may have been interpreted better in their own minds than in their written accounts that were culturally translated for a French mentality.

Third, the Iberian mistakes will lead to alternative interpretations, or hypotheses, of Amerindian culture. The cultural framework that the French Jesuits forced upon their interpretation of the native religion helped them to understand it, but at the same time it helped them to ignore differences of each element. The native religion that the Jesuits claimed to have discovered may not have been a coherent religion and may have been instead a series of independent beliefs and fables that were not necessarily relevant with one another. As was the result in Japan, the French Jesuits' academic achievement is that they reconstructed, for the imagination held by their European readers back home, a Jesuit version of Amerindian religion that had perhaps never existed as the systematical counterpart of their Euro-Christian religious concept.

There may be alternative interpretations when the Euro-Christian biases are considered in the Jesuit descriptions. For example, just as the concept of the Creation is alien to Buddhism, the Amerindian Creator may not have been an important component in the Huron belief in spirits. The Creator was not an object for religious worship. There was no 'Heaven' in indigenous beliefs. The native notion of the soul and its immortality was different from the Christian idea, and may have been something like eternal spirits that were believed to move from one body to another in a single secular world that lacked a Heaven. The concept of manitou or oki may have been related to these eternal spirits although the missionaries did not even hint at the connection between them. The indigenous people believed in supernatural powers and called them 'manitou' or 'oki', but they should not be connected immediately with the deity that was equivalent to the opponent to the Christian God. The native manitou or oki could be both good and bad, and the notion of devils or demons did not exist among the Amerindians before the mission. 